\title{
Internal Medicine Milestones
}

The Accreditation Council for Graduate Medical Education

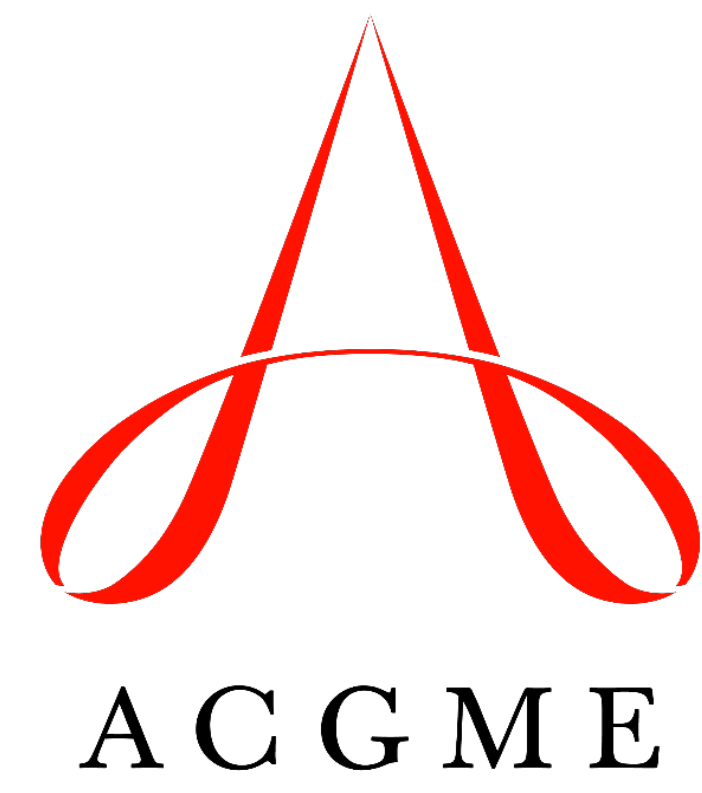

Implementation Date: July 1, 2021 Second Revision: November 2020

First Revision: July 2013 


\section{Internal Medicine Milestones}

The Milestones are designed only for use in evaluation of residents in the context of their participation in ACGME-accredited residency programs. The Milestones provide a framework for the assessment of the development of the resident in key dimensions of the elements of physician competency in a specialty or subspecialty. They neither represent the entirety of the dimensions of the six domains of physician competency, nor are they designed to be relevant in any other context. 


\section{Internal Medicine Milestones \\ Work Group}

Eva Aagaard, MD, FACP

Cinnamon Bradley, MD

Fred Buckhold, MD

Alfred Burger, MD, MS, FACP, SFHM

Stephanie Call, MD, MSPH

Shobhina Chheda, MD, MPH

Davoren Chick, MD, FACP

Jack DePriest, MD, MACM

Benjamin Doolittle, MD, MDiv

Laura Edgar, EdD, CAE

Christin Giordano McAuliffe, MD

Neil Kothari, MD

Heather Laird-Fick, MD, MPH, FACP

\section{Advisory Group}

Mobola Campbell-Yesufu, MD, MPH

Gretchen Diemer, MD

Jodi Friedman, MD

Janae Heath, MD

Benjamin Kinnear, MD
Jonathan Lim, MD

Monica Lypson, MD, MHPE

Allan Markus, MD, MS, MBA, FACP

Bernadette Miller, MD

Attila Nemeth, MD

Jacob Perrin, MD

Raul Ramirez Velazquez, DO

Rachel Robbins, MD

Jacqueline Stocking, PhD, MBA, RN

Jane Trinh, MD

Mark Tschanz, DO, MACM

Asher Tulsky, MD

Eric Warm, MD

Subha Ramani, MBBS, MMed, MPH

Brijen Shah, MD

C. Christopher Smith, MD

Abby Spencer, MD, MS

Nicole Swallow, MD, FACP 
The ACGME would like to thank the following organizations for their continued support in the development of the Milestones:

\author{
Alliance for Academic Internal Medicine \\ American Board of Internal Medicine \\ American College of Physicians \\ Association of Medical Colleges \\ Review Committee for Internal Medicine \\ Society of Hospital Medicine \\ Society of General Internal Medicine
}




\section{Understanding Milestone Levels and Reporting}

This document presents the Milestones, which programs use in a semi-annual review of resident performance, and then report to the ACGME. Milestones are knowledge, skills, attitudes, and other attributes for each of the ACGME Competencies organized in a developmental framework. The narrative descriptions are targets for resident performance throughout their educational program.

Milestones are arranged into levels. Tracking from Level 1 to Level 5 is synonymous with moving from novice to expert resident in the specialty or subspecialty. For each reporting period, the Clinical Competency Committee will review the completed evaluations to select the milestone levels that best describe each learner's current performance, abilities, and attributes for each subcompetency.

These levels do not correspond with post-graduate year of education. Depending on previous experience, a junior resident may achieve higher levels early in his/her educational program just as a senior resident may be at a lower level later in his/her educational program. There is no predetermined timing for a resident to attain any particular level. Residents may also regress in achievement of their milestones. This may happen for many reasons, such as over scoring in a previous review, a disjointed experience in a particular procedure, or a significant act by the resident.

Selection of a level implies the resident substantially demonstrates the milestones in that level, as well as those in lower levels (see the diagram on page vi). 


\section{Additional Notes}

Level 4 is designed as a graduation goal but does not represent a graduation requirement. Making decisions about readiness for graduation and unsupervised practice is the purview of the program director. Furthermore, Milestones 2.0 include revisions and changes that preclude using Milestones as a sole assessment in high-stakes decisions (i.e., determination of eligibility for certification or credentialing). Level 5 is designed to represent an expert resident whose achievements in a subcompetency are greater than the expectation. Milestones are primarily designed for formative, developmental purposes to support continuous quality improvement for individual learners, education programs, and the specialty. The ACGME and its partners will continue to evaluate and perform research on the Milestones to assess their impact and value.

Examples are provided for some milestones within this document. Please note: the examples are not the required element or outcome; they are provided as a way to share the intent of the element.

Some milestone descriptions include statements about performing independently. These activities must occur in conformity to ACGME supervision guidelines as described in the Program Requirements, as well as to institutional and program policies. For example, a resident who performs a procedure independently must, at a minimum, be supervised through oversight.

A Supplemental Guide is also available to provide the intent of each subcompetency, examples for each level, assessment methods or tools, and other available resources. The Supplemental Guide, like examples contained within the Milestones, is designed only to assist the program director and Clinical Competency Committee, and is not meant to demonstrate any required element or outcome.

Additional resources are available in the Milestones section of the ACGME website. Follow the links under "What We Do" at www.acgme.org. 
The diagram below presents an example set of milestones for one sub-competency in the same format as the ACGME Report Worksheet. For each reporting period, a resident's performance on the milestones for each sub-competency will be indicated by selecting the level of milestones that best describes that resident's performance in relation to those milestones.

\begin{tabular}{|c|c|c|c|c|}
\hline \multicolumn{5}{|c|}{ Systems-based Practice 1: Patient Safety and Quality Improvement } \\
\hline Level 1 & Level 2 & Level 3 & Level 4 & Level 5 \\
\hline $\begin{array}{l}\text { Demonstrates } \\
\text { knowledge of common } \\
\text { patient safety events }\end{array}$ & $\begin{array}{l}\text { Identifies system factors } \\
\text { that lead to patient safety } \\
\text { events }\end{array}$ & $\begin{array}{l}\text { Participates in analysis of } \\
\text { patient safety events } \\
\text { (simulated or actual) }\end{array}$ & $\begin{array}{l}\text { Conducts analysis of } \\
\text { patient safety events } \\
\text { and offers error } \\
\text { prevention strategies } \\
\text { (simulated or actual) }\end{array}$ & $\begin{array}{l}\text { Actively engages teams } \\
\text { and processes to modify } \\
\text { systems to prevent } \\
\text { patient safety events }\end{array}$ \\
\hline $\begin{array}{l}\text { Demonstrates } \\
\text { knowledge of how to } \\
\text { report patient safety } \\
\text { events }\end{array}$ & $\begin{array}{l}\text { Reports patient safety } \\
\text { events through } \\
\text { institutional reporting } \\
\text { systems (simulated or } \\
\text { actual) }\end{array}$ & $\begin{array}{l}\text { Participates in disclosure } \\
\text { of patient safety events to } \\
\text { patients and families } \\
\text { (simulated or actual) }\end{array}$ & $\begin{array}{l}\text { Discloses patient safety } \\
\text { events to patients and } \\
\text { families (simulated or } \\
\text { actual) }\end{array}$ & $\begin{array}{l}\text { Role models or mentors } \\
\text { others in the disclosure of } \\
\text { patient safety events }\end{array}$ \\
\hline $\begin{array}{l}\text { Demonstrates } \\
\text { knowledge of basic } \\
\text { quality improvement } \\
\text { methodologies and } \\
\text { metrics }\end{array}$ & $\begin{array}{l}\text { Describes local quality } \\
\text { improvement initiatives } \\
\text { (e.g., community } \\
\text { vaccination rate, infection } \\
\text { rate, smoking cessation) }\end{array}$ & $\begin{array}{l}\text { Participates in local } \\
\text { quality improvement } \\
\text { initiatives }\end{array}$ & $\begin{array}{l}\text { Demonstrates skills } \\
\text { required to identify, } \\
\text { develop, implement, } \\
\text { and analyze a quality } \\
\text { improvement project }\end{array}$ & $\begin{array}{l}\text { Designs, implements, } \\
\text { and assesses quality } \\
\text { improvement initiatives at } \\
\text { the institutional or } \\
\text { community level }\end{array}$ \\
\hline & & & $\square$ & $\square$ \\
\hline \multicolumn{5}{|l|}{ Comments: } \\
\hline \multicolumn{2}{|c|}{$\begin{array}{l}\text { Selecting a response box in the } \\
\text { middle of a level implies that } \\
\text { milestones in that level and in lower } \\
\text { levels have been substantially } \\
\text { demonstrated. }\end{array}$} & & \multicolumn{2}{|c|}{$\begin{array}{l}\text { Selecting a response box on the line in } \\
\text { between levels indicates that milestones } \\
\text { in lower levels have been substantially } \\
\text { demonstrated as well as some } \\
\text { milestones in the higher level(s). }\end{array}$} \\
\hline
\end{tabular}




\section{Patient Care 1: History}

\begin{tabular}{|c|c|c|c|c|}
\hline Level 1 & Level 2 & Level 3 & Level 4 & Level 5 \\
\hline $\begin{array}{l}\text { Elicits and reports a } \\
\text { comprehensive history } \\
\text { for common patient } \\
\text { presentations, with } \\
\text { guidance }\end{array}$ & $\begin{array}{l}\text { Elicits and concisely } \\
\text { reports a hypothesis- } \\
\text { driven patient history for } \\
\text { common patient } \\
\text { presentations }\end{array}$ & $\begin{array}{l}\text { Elicits and concisely } \\
\text { reports a hypothesis- } \\
\text { driven patient history for } \\
\text { complex patient } \\
\text { presentations }\end{array}$ & $\begin{array}{l}\text { Efficiently elicits and } \\
\text { concisely reports a } \\
\text { patient history, } \\
\text { incorporating pertinent } \\
\text { psychosocial and other } \\
\text { determinants of health }\end{array}$ & $\begin{array}{l}\text { Efficiently and effectively } \\
\text { tailors the history taking, } \\
\text { including relevant } \\
\text { historical subtleties, } \\
\text { based on patient, family, } \\
\text { and system needs }\end{array}$ \\
\hline
\end{tabular}

Comments:

Not Yet Completed Level 1 Not Yet Assessable 


\section{Patient Care 2: Physical Examination}

\begin{tabular}{|c|c|c|c|c|}
\hline Level 1 & Level 2 & Level 3 & Level 4 & Level 5 \\
\hline $\begin{array}{l}\text { Performs a general } \\
\text { physical examination } \\
\text { while attending to patient } \\
\text { comfort and safety }\end{array}$ & $\begin{array}{l}\text { Performs a hypothesis- } \\
\text { driven physical } \\
\text { examination for a } \\
\text { common patient } \\
\text { presentation }\end{array}$ & $\begin{array}{l}\text { Performs a hypothesis- } \\
\text { driven physical } \\
\text { examination for a } \\
\text { complex patient } \\
\text { presentation }\end{array}$ & $\begin{array}{l}\text { Uses advanced } \\
\text { maneuvers to elicit } \\
\text { subtle findings }\end{array}$ & $\begin{array}{l}\text { Models effective } \\
\text { evidence-based physical } \\
\text { examination technique }\end{array}$ \\
\hline $\begin{array}{l}\text { Identifies common } \\
\text { abnormal findings }\end{array}$ & $\begin{array}{l}\text { Interprets common } \\
\text { abnormal findings }\end{array}$ & $\begin{array}{l}\text { Identifies and interprets } \\
\text { uncommon and complex } \\
\text { abnormal findings }\end{array}$ & $\begin{array}{l}\text { Integrates subtle } \\
\text { physical examination } \\
\text { findings to guide } \\
\text { diagnosis and } \\
\text { management }\end{array}$ & $\begin{array}{l}\text { Teaches the predictive } \\
\text { values of the examination } \\
\text { findings to guide } \\
\text { diagnosis and } \\
\text { management }\end{array}$ \\
\hline
\end{tabular}

\section{Comments:}




\section{Patient Care 3: Clinical Reasoning}

\begin{tabular}{|c|c|c|c|c|}
\hline \multirow[b]{2}{*}{$\begin{array}{l}\text { Level } 1 \\
\text { Organizes and } \\
\text { accurately summarizes } \\
\text { information obtained } \\
\text { from the patient } \\
\text { evaluation to develop a } \\
\text { clinical impression }\end{array}$} & $\begin{array}{l}\text { Level } 2 \\
\text { Integrates information } \\
\text { from all sources to } \\
\text { develop a basic } \\
\text { differential diagnosis for } \\
\text { common patient } \\
\text { presentations }\end{array}$ & $\begin{array}{l}\text { Level } 3 \\
\text { Develops a thorough and } \\
\text { prioritized differential } \\
\text { diagnosis for common } \\
\text { patient presentations }\end{array}$ & Level 4 & Level 5 \\
\hline & $\begin{array}{l}\text { Integrates information } \\
\text { from all sources to } \\
\text { develop a basic } \\
\text { differential diagnosis for } \\
\text { common patient } \\
\text { presentations } \\
\\
\text { Identifies clinical } \\
\text { reasoning errors within } \\
\text { patient care, with } \\
\text { guidance }\end{array}$ & $\begin{array}{l}\text { Retrospectively applies } \\
\text { clinical reasoning } \\
\text { principles to identify } \\
\text { errors }\end{array}$ & $\begin{array}{l}\text { Develops prioritized } \\
\text { differential diagnoses in } \\
\text { complex patient } \\
\text { presentations and } \\
\text { incorporates subtle, } \\
\text { unusual, or conflicting } \\
\text { findings } \\
\text { Continually re-appraises } \\
\text { one's own clinical } \\
\text { reasoning to improve } \\
\text { patient care in real time }\end{array}$ & $\begin{array}{l}\text { Coaches others to } \\
\text { develop prioritized } \\
\text { differential diagnoses in } \\
\text { complex patient } \\
\text { presentations } \\
\\
\text { Models how to recognize } \\
\text { errors and reflect upon } \\
\text { one's own clinical } \\
\text { reasoning }\end{array}$ \\
\hline & & & & \\
\hline & & & $\begin{array}{l}\text { Not Yet C } \\
\text { Not Yet A }\end{array}$ & $\begin{array}{l}\text { ompleted Level } 1 \\
\text { ssessable }\end{array}$ \\
\hline
\end{tabular}




\section{Patient Care 4: Patient Management - Inpatient}

\begin{tabular}{|c|c|c|c|c|}
\hline $\begin{array}{l}\text { Level } 1 \\
\text { Formulates managemen } \\
\text { plans for common } \\
\text { conditions, with guidanc }\end{array}$ & Level 2 & Level 3 & Level 4 & Level 5 \\
\hline $\begin{array}{l}\text { Formulates management } \\
\text { plans for common } \\
\text { conditions, with guidance }\end{array}$ & $\begin{array}{l}\text { Develops and implements } \\
\text { management plans for } \\
\text { common conditions, } \\
\text { recognizing acuity, and } \\
\text { modifies based on the } \\
\text { clinical course }\end{array}$ & $\begin{array}{l}\text { Develops and implements } \\
\text { value-based (high value) } \\
\text { management plans for } \\
\text { patients with multisystem } \\
\text { disease and comorbid } \\
\text { conditions; modifies } \\
\text { based on the clinical } \\
\text { course }\end{array}$ & $\begin{array}{l}\text { Uses shared decision } \\
\text { making to develop and } \\
\text { implement value-based } \\
\text { (high value) } \\
\text { comprehensive } \\
\text { management plans for } \\
\text { patients with comorbid } \\
\text { and multisystem } \\
\text { disease, including those } \\
\text { patients requiring critical } \\
\text { care }\end{array}$ & $\begin{array}{l}\text { Develops and implements } \\
\text { comprehensive } \\
\text { management plans for } \\
\text { patients with rare or } \\
\text { ambiguous presentations } \\
\text { or unusual comorbid } \\
\text { conditions }\end{array}$ \\
\hline $\begin{array}{l}\text { Identifies opportunities to } \\
\text { maintain and promote } \\
\text { health }\end{array}$ & $\begin{array}{l}\text { Develops and implements } \\
\text { management plans to } \\
\text { maintain and promote } \\
\text { health, with guidance }\end{array}$ & $\begin{array}{l}\text { Independently develops } \\
\text { and implements plans to } \\
\text { maintain and promote } \\
\text { health, incorporating } \\
\text { pertinent psychosocial } \\
\text { and other determinants of } \\
\text { health }\end{array}$ & $\begin{array}{l}\text { Independently develops } \\
\text { and implements } \\
\text { comprehensive plans to } \\
\text { maintain and promote } \\
\text { health, incorporating } \\
\text { pertinent psychosocial } \\
\text { and other determinants } \\
\text { of health }\end{array}$ & \\
\hline & & & & \\
\hline
\end{tabular}

Comments:

Not Yet Completed Level 1

Not Yet Assessable 
Patient Care 5: Patient Management - Outpatient

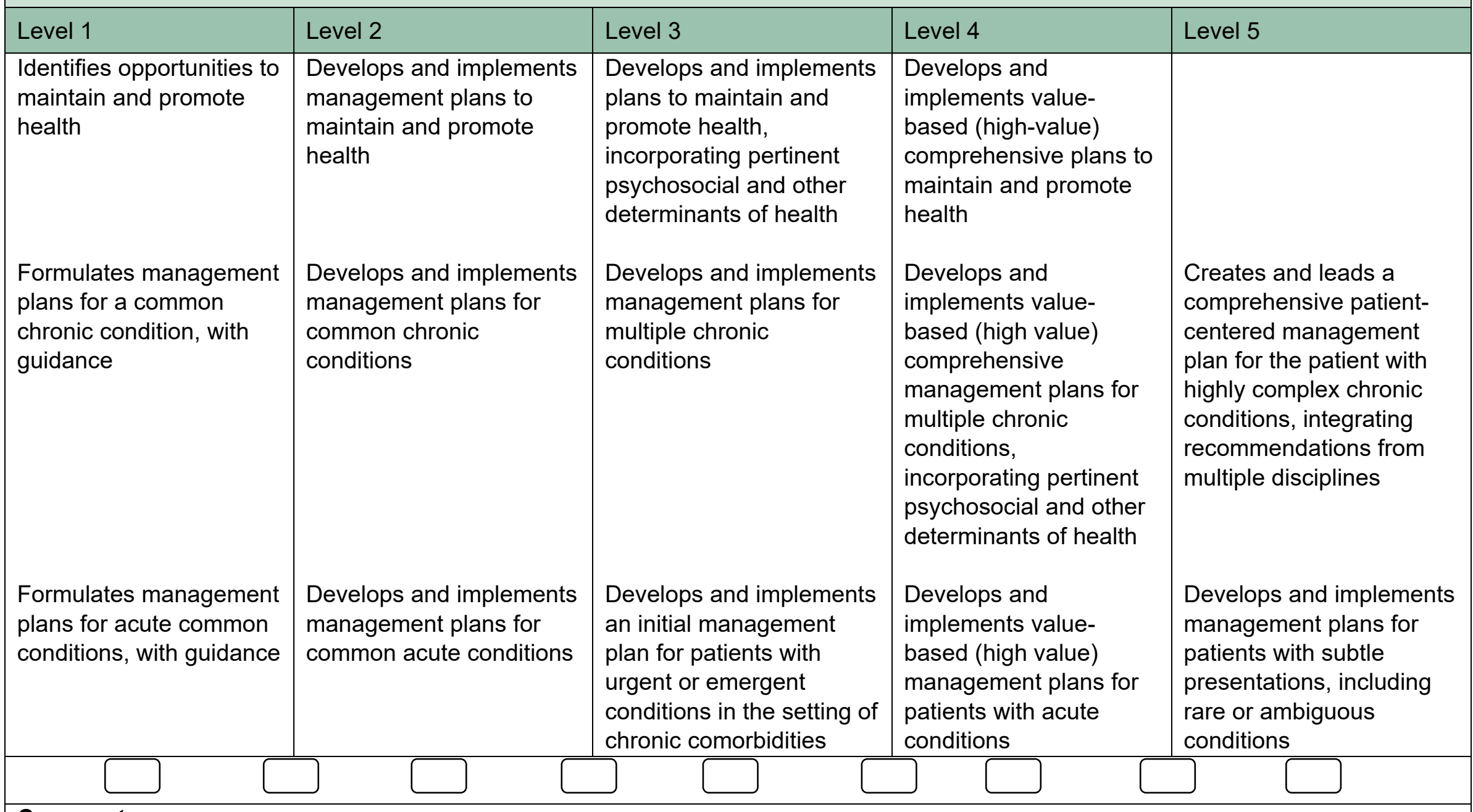

\section{Comments:}




\section{Patient Care 6: Digital Health}

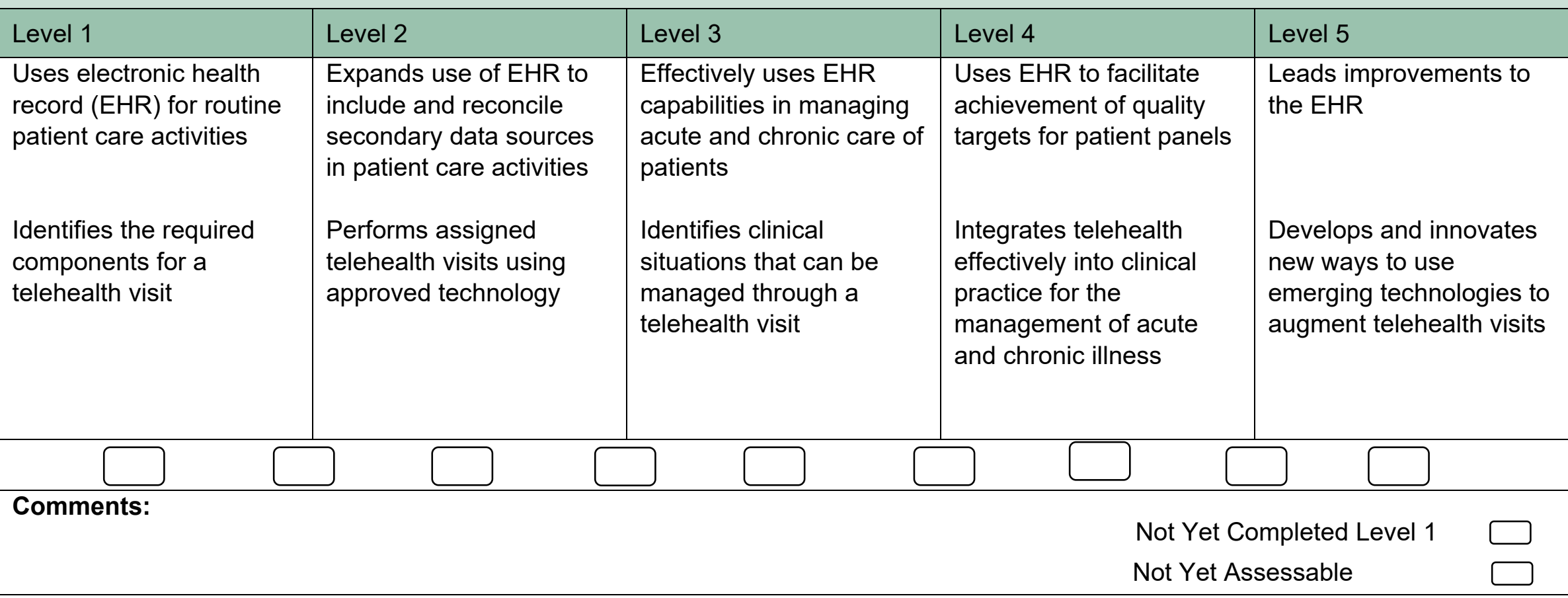

\section{Patient Care}

The resident is demonstrating satisfactory development of the knowledge, skill, and attitudes/behaviors needed to advance in the training program. The resident is demonstrating a learning trajectory that anticipates the achievement of competency for unsupervised practice that includes the delivery of safe, effective, patient-centered, timely, efficient, and equitable care.

Yes

No

Conditional on Improvement 


\section{Medical Knowledge 1: Applied Foundational Sciences}

\begin{tabular}{|l|l|l|l|l|}
\hline Level 1 & Level 2 & Level 3 & Level 4 & Level 5 \\
\hline $\begin{array}{l}\text { Explains the scientific } \\
\text { knowledge (e.g., } \\
\text { physiology, social } \\
\text { sciences, mechanism of } \\
\text { disease) for normal } \\
\text { function and common } \\
\text { medical conditions }\end{array}$ & $\begin{array}{l}\text { Explains the scientific } \\
\text { knowledge for complex } \\
\text { medical conditions }\end{array}$ & $\begin{array}{l}\text { Integrates scientific } \\
\text { knowledge to address } \\
\text { comorbid conditions } \\
\text { within the context of } \\
\text { multisystem disease }\end{array}$ & $\begin{array}{l}\text { Integrates scientific } \\
\text { knowledge to address } \\
\text { uncommon, atypical, or } \\
\text { complex comorbid } \\
\text { conditions within the } \\
\text { context of multisystem } \\
\text { disease }\end{array}$ & $\begin{array}{l}\text { Demonstrates a nuanced } \\
\text { understanding of the } \\
\text { scientific knowledge } \\
\text { related to uncommon, } \\
\text { atypical, or complex } \\
\text { conditions }\end{array}$ \\
\hline Comments:
\end{tabular}




\section{Medical Knowledge 2: Therapeutic Knowledge}

\begin{tabular}{|l|l|l|l|l|}
\hline Level 1 & Level 2 & Level 3 & Level 4 & Level 5 \\
\hline $\begin{array}{l}\text { Explains the scientific } \\
\text { basis for common } \\
\text { therapies }\end{array}$ & $\begin{array}{l}\text { Explains the indications, } \\
\text { contraindications, risks, } \\
\text { and benefits of common } \\
\text { therapies }\end{array}$ & $\begin{array}{l}\text { Integrates knowledge of } \\
\text { therapeutic options in } \\
\text { patients with comorbid } \\
\text { conditions, multisystem } \\
\text { disease, or uncertain } \\
\text { diagnosis }\end{array}$ & $\begin{array}{l}\text { Integrates knowledge of } \\
\text { therapeutic options } \\
\text { within the clinical and } \\
\text { psychosocial context of } \\
\text { the patient to formulate } \\
\text { treatment options }\end{array}$ & $\begin{array}{l}\text { Demonstrates a nuanced } \\
\text { understanding of } \\
\text { emerging, atypical, or } \\
\text { complex therapeutic } \\
\text { options }\end{array}$ \\
\hline
\end{tabular}

\section{Comments:}




\section{Medical Knowledge 3: Knowledge of Diagnostic Testing}

\begin{tabular}{|c|c|c|c|c|}
\hline Level 1 & Level 2 & Level 3 & Level 4 & Level 5 \\
\hline $\begin{array}{l}\text { Interprets results of } \\
\text { common diagnostic tests }\end{array}$ & $\begin{array}{l}\text { Interprets complex } \\
\text { diagnostic data }\end{array}$ & $\begin{array}{l}\text { Integrates value and test } \\
\text { characteristics of various } \\
\text { diagnostic strategies in } \\
\text { patients with common } \\
\text { diseases } \\
\text { Integrates complex } \\
\text { diagnostic data accurately } \\
\text { to reach high-probability } \\
\text { diagnoses }\end{array}$ & $\begin{array}{l}\text { Integrates value and } \\
\text { test characteristics of } \\
\text { various diagnostic } \\
\text { strategies in patients } \\
\text { with comorbid } \\
\text { conditions or } \\
\text { multisystem disease } \\
\text { Anticipates and } \\
\text { accounts for limitations } \\
\text { when interpreting } \\
\text { diagnostic data }\end{array}$ & $\begin{array}{l}\text { Demonstrates a nuanced } \\
\text { understanding of } \\
\text { emerging diagnostic tests } \\
\text { and procedures }\end{array}$ \\
\hline \multicolumn{5}{|l|}{ Comments: } \\
\hline \multicolumn{5}{|c|}{$\begin{array}{l}\text { Not Yet Completed Level } 1 \\
\text { Not Yet Assessable }\end{array}$} \\
\hline
\end{tabular}

\section{Medical Knowledge}

The resident is demonstrating satisfactory development of the knowledge, skill, and attitudes/behaviors needed to advance in the training program. The resident is demonstrating a learning trajectory that anticipates the achievement of competency for unsupervised practice that includes the delivery of safe, effective, patient-centered, timely, efficient, and equitable care.

Yes No Conditional on Improvement 


\section{Systems-Based Practice 1: Patient Safety and Quality Improvement}

\begin{tabular}{|c|c|c|c|c|}
\hline Level 1 & Level 2 & Level 3 & Level 4 & Level 5 \\
\hline $\begin{array}{l}\text { Demonstrates } \\
\text { knowledge of common } \\
\text { patient safety events }\end{array}$ & $\begin{array}{l}\text { Identifies system factors } \\
\text { that lead to patient safety } \\
\text { events }\end{array}$ & $\begin{array}{l}\text { Contributes to the } \\
\text { analysis of patient safety } \\
\text { events (simulated or } \\
\text { actual) }\end{array}$ & $\begin{array}{l}\text { Conducts analysis of } \\
\text { patient safety events } \\
\text { and offers error } \\
\text { prevention strategies } \\
\text { (simulated or actual) }\end{array}$ & $\begin{array}{l}\text { Leads teams and } \\
\text { processes to modify } \\
\text { systems to prevent } \\
\text { patient safety events }\end{array}$ \\
\hline $\begin{array}{l}\text { Demonstrates } \\
\text { knowledge of how to } \\
\text { report patient safety } \\
\text { events }\end{array}$ & $\begin{array}{l}\text { Reports patient safety } \\
\text { events through } \\
\text { institutional reporting } \\
\text { systems (actual or } \\
\text { simulated) }\end{array}$ & $\begin{array}{l}\text { Participates in disclosure } \\
\text { of patient safety events to } \\
\text { patients and families } \\
\text { (simulated or actual) }\end{array}$ & $\begin{array}{l}\text { Discloses patient safety } \\
\text { events to patients and } \\
\text { families (simulated or } \\
\text { actual) }\end{array}$ & $\begin{array}{l}\text { Models the disclosure of } \\
\text { patient safety events }\end{array}$ \\
\hline $\begin{array}{l}\text { Demonstrates } \\
\text { knowledge of basic } \\
\text { quality improvement } \\
\text { methodologies and } \\
\text { metrics }\end{array}$ & $\begin{array}{l}\text { Describes local quality } \\
\text { improvement initiatives } \\
\text { (e.g., community } \\
\text { vaccination rate, infection } \\
\text { rate, smoking cessation) }\end{array}$ & $\begin{array}{l}\text { Contributes to local } \\
\text { quality improvement } \\
\text { initiatives }\end{array}$ & $\begin{array}{l}\text { Demonstrates the skills } \\
\text { required to identify, } \\
\text { develop, implement, } \\
\text { and analyze a quality } \\
\text { improvement project }\end{array}$ & $\begin{array}{l}\text { Creates, implements, and } \\
\text { assesses sustainable } \\
\text { quality improvement } \\
\text { initiatives at the } \\
\text { institutional or community } \\
\text { level }\end{array}$ \\
\hline & & & & \\
\hline
\end{tabular}

Comments: 


\section{Systems-Based Practice 2: System Navigation for Patient-Centered Care}

\begin{tabular}{|c|c|c|c|c|}
\hline Level 1 & Level 2 & Level 3 & Level 4 & Level 5 \\
\hline $\begin{array}{l}\text { Demonstrates } \\
\text { knowledge of care } \\
\text { coordination }\end{array}$ & $\begin{array}{l}\text { Coordinates care of } \\
\text { patients by effectively } \\
\text { engaging } \\
\text { interprofessional teams in } \\
\text { routine clinical situations }\end{array}$ & $\begin{array}{l}\text { Coordinates care of } \\
\text { patients by effectively } \\
\text { engaging } \\
\text { interprofessional teams in } \\
\text { complex clinical situations }\end{array}$ & $\begin{array}{l}\text { Models effective } \\
\text { coordination of patient- } \\
\text { centered care among } \\
\text { different disciplines and } \\
\text { specialties }\end{array}$ & $\begin{array}{l}\text { Analyzes the process of } \\
\text { care coordination and } \\
\text { leads in the design and } \\
\text { implementation of } \\
\text { improvements }\end{array}$ \\
\hline $\begin{array}{l}\text { Identifies key elements } \\
\text { for safe and effective } \\
\text { transitions of care and } \\
\text { hand-offs }\end{array}$ & $\begin{array}{l}\text { Performs safe and } \\
\text { effective transitions of } \\
\text { care/hand-offs in routine } \\
\text { clinical situations }\end{array}$ & $\begin{array}{l}\text { Performs safe and } \\
\text { effective transitions of } \\
\text { care/hand-offs in complex } \\
\text { clinical situations }\end{array}$ & $\begin{array}{l}\text { Models and advocates } \\
\text { for safe and effective } \\
\text { transitions of care/hand- } \\
\text { offs within and across } \\
\text { health care delivery } \\
\text { systems, including } \\
\text { outpatient settings }\end{array}$ & $\begin{array}{l}\text { Improves quality of } \\
\text { transitions of care within } \\
\text { and across health care } \\
\text { delivery systems to } \\
\text { optimize patient outcomes }\end{array}$ \\
\hline $\begin{array}{l}\text { Demonstrates } \\
\text { knowledge of population } \\
\text { and community health } \\
\text { needs and disparities }\end{array}$ & $\begin{array}{l}\text { Identifies specific } \\
\text { population and } \\
\text { community health needs } \\
\text { and inequities for the local } \\
\text { population }\end{array}$ & $\begin{array}{l}\text { Uses local resources } \\
\text { effectively to meet the } \\
\text { needs of a patient } \\
\text { population and } \\
\text { community }\end{array}$ & $\begin{array}{l}\text { Participates in changing } \\
\text { and adapting practice to } \\
\text { provide for the needs of } \\
\text { specific populations }\end{array}$ & $\begin{array}{l}\text { Leads innovations and } \\
\text { advocates for populations } \\
\text { and communities with } \\
\text { health care inequities }\end{array}$ \\
\hline & & & & \\
\hline
\end{tabular}

Not Yet Completed Level 1 


\section{Systems-Based Practice 3: Physician Role in Health Care Systems}

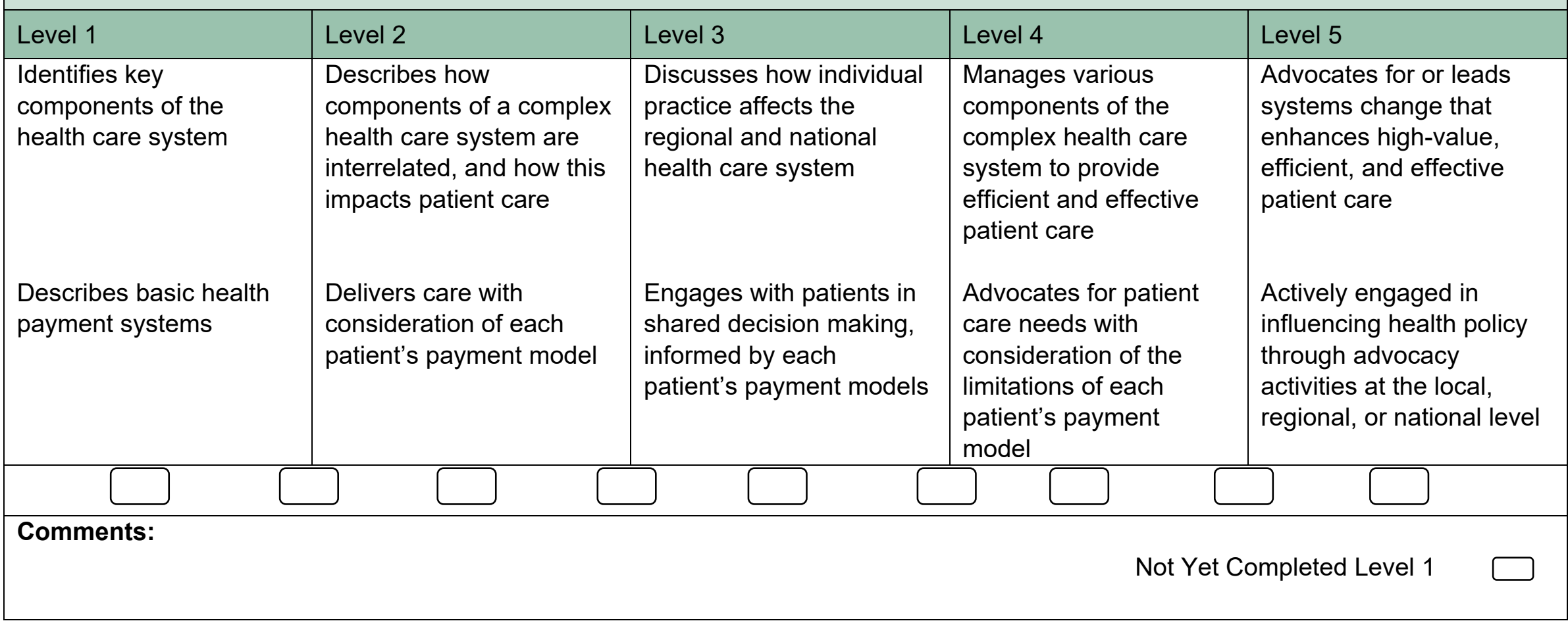

\section{Systems-Based Practice}

The resident is demonstrating satisfactory development of the knowledge, skill, and attitudes/behaviors needed to advance in the training program. The resident is demonstrating a learning trajectory that anticipates the achievement of competency for unsupervised practice that includes the delivery of safe, effective, patient-centered, timely, efficient, and equitable care.

Yes No Conditional on Improvement 


\section{Practice-Based Learning and Improvement 1: Evidence-Based and Informed Practice}

\begin{tabular}{|l|l|l|l|l|}
\hline Level 1 & Level 2 & Level 3 & Level 4 & Level 5 \\
\hline $\begin{array}{l}\text { Demonstrates how to } \\
\text { access, categorize, and } \\
\text { evidence, with guidance }\end{array}$ & $\begin{array}{l}\text { Articulates clinical } \\
\text { questions and elicits } \\
\text { patient preferences and } \\
\text { values to guide evidence- } \\
\text { based care }\end{array}$ & $\begin{array}{l}\text { Critically appraises and } \\
\text { applies the best available } \\
\text { evidence, integrated with } \\
\text { patient preference, to the } \\
\text { care of complex patients }\end{array}$ & $\begin{array}{l}\text { Applies evidence, even } \\
\text { in the face of } \\
\text { uncertainty and } \\
\text { conflicting evidence, to } \\
\text { guide care, tailored to } \\
\text { the individual patient }\end{array}$ & $\begin{array}{l}\text { Coaches others to } \\
\text { critically appraise and } \\
\text { apply evidence to patient } \\
\text { care }\end{array}$ \\
\hline
\end{tabular}

Comments:

Not Yet Completed Level 1 


\section{Practice-Based Learning and Improvement 2: Reflective Practice and Commitment to Personal Growth}

\begin{tabular}{|c|c|c|c|c|}
\hline Level 1 & Level 2 & Level 3 & Level 4 & Level 5 \\
\hline \multirow{3}{*}{$\begin{array}{l}\text { Accepts responsibility for } \\
\text { personal and } \\
\text { professional } \\
\text { development by } \\
\text { establishing goals } \\
\text { Identifies the factors that } \\
\text { contribute to gap(s) } \\
\text { between ideal and actual } \\
\text { performance, with } \\
\text { guidance }\end{array}$} & $\begin{array}{l}\text { Demonstrates openness } \\
\text { to performance data } \\
\text { (feedback and other } \\
\text { input) to inform goals }\end{array}$ & $\begin{array}{l}\text { Seeks performance data } \\
\text { episodically, with } \\
\text { adaptability, and humility }\end{array}$ & $\begin{array}{l}\text { Seeks performance } \\
\text { data consistently with } \\
\text { adaptability, and } \\
\text { humility }\end{array}$ & $\begin{array}{l}\text { Models consistently } \\
\text { seeking performance data } \\
\text { with adaptability and } \\
\text { humility }\end{array}$ \\
\hline & \multirow{2}{*}{$\begin{array}{l}\text { Analyzes and reflects on } \\
\text { the factors which } \\
\text { contribute to gap(s) } \\
\text { between ideal and actual } \\
\text { performance, with } \\
\text { guidance } \\
\text { Actively seeks } \\
\text { opportunities to improve }\end{array}$} & $\begin{array}{l}\text { Institutes behavioral } \\
\text { change(s) to narrow the } \\
\text { gap(s) between ideal and } \\
\text { actual performance }\end{array}$ & $\begin{array}{l}\text { Challenges one's own } \\
\text { assumptions and } \\
\text { considers alternatives in } \\
\text { narrowing the gap(s) } \\
\text { between ideal and } \\
\text { actual performance }\end{array}$ & $\begin{array}{l}\text { Coaches others on } \\
\text { reflective practice }\end{array}$ \\
\hline & & $\begin{array}{l}\text { Designs and implements } \\
\text { an individualized learning } \\
\text { plan, with prompting }\end{array}$ & $\begin{array}{l}\text { Independently creates } \\
\text { and implements an } \\
\text { individualized learning } \\
\text { plan }\end{array}$ & $\begin{array}{l}\text { Uses performance data to } \\
\text { measure the } \\
\text { effectiveness of the } \\
\text { individualized learning } \\
\text { plan and when necessary, } \\
\text { improves it }\end{array}$ \\
\hline & & & & \\
\hline & & & Not $\mathrm{Ye}$ & ompleted Level 1 \\
\hline
\end{tabular}

\section{Practice-Based Learning and Improvement}

The resident is demonstrating satisfactory development of the knowledge, skill, and attitudes/behaviors needed to advance in the training program. The resident is demonstrating a learning trajectory that anticipates the achievement of competency for unsupervised practice that includes the delivery of safe, effective, patient-centered, timely, efficient, and equitable care.

Yes No Conditional on Improvement 


\section{Professionalism 1: Professional Behavior}

\begin{tabular}{|l|l|l|l|l|}
\hline Level 1 & Level 2 & Level 3 & Level 4 & Level 5 \\
\hline $\begin{array}{l}\text { Demonstrates } \\
\text { professional behavior in } \\
\text { routine situations }\end{array}$ & $\begin{array}{l}\text { Identifies potential } \\
\text { triggers for } \\
\text { professionalism lapses } \\
\text { and accepts responsibility } \\
\text { for one's own } \\
\text { professionalism lapses }\end{array}$ & $\begin{array}{l}\text { Demonstrates a pattern of } \\
\text { professional behavior in } \\
\text { complex or stressful } \\
\text { situations }\end{array}$ & $\begin{array}{l}\text { Recognizes situations } \\
\text { that may trigger } \\
\text { professionalism lapses } \\
\text { and intervenes to } \\
\text { prevent lapses in } \\
\text { oneself and others }\end{array}$ & $\begin{array}{l}\text { Coaches others when } \\
\text { their behavior fails to } \\
\text { meet professional } \\
\text { expectations }\end{array}$ \\
\hline
\end{tabular}

Comments:

Not Yet Completed Level 1 


\section{Professionalism 2: Ethical Principles}

\begin{tabular}{|l|l|l|l|l|}
\hline Level 1 & Level 2 & Level 3 & Level 4 & Level 5 \\
$\begin{array}{l}\text { Demonstrates } \\
\text { knowledge of basic } \\
\text { ethical principles }\end{array}$ & $\begin{array}{l}\text { Applies basic principles to } \\
\text { address straightforward } \\
\text { ethical situations }\end{array}$ & $\begin{array}{l}\text { Analyzes complex } \\
\text { situations using ethical } \\
\text { principles and identifies } \\
\text { the need to seek help in } \\
\text { addressing complex } \\
\text { ethical situations }\end{array}$ & $\begin{array}{l}\text { Analyzes complex } \\
\text { situations and engages } \\
\text { with appropriate } \\
\text { resources for managing } \\
\text { and addressing ethical } \\
\text { dilemmas as needed }\end{array}$ & $\begin{array}{l}\text { Identifies and seeks to } \\
\text { address system-level } \\
\text { factors that induce or } \\
\text { exacerbate ethical } \\
\text { problems or impede their } \\
\text { resolution }\end{array}$
\end{tabular}

\section{Comments:}




\section{Professionalism 3: Accountability/Conscientiousness}

\begin{tabular}{|l|l|l|l|l|}
\hline Level 1 & Level 2 & Level 3 & Level 4 & Level 5 \\
\hline $\begin{array}{l}\text { Performs administrative } \\
\text { tasks and patient care } \\
\text { responsibilities, with } \\
\text { prompting }\end{array}$ & $\begin{array}{l}\text { Performs administrative } \\
\text { tasks and patient care } \\
\text { responsibilities in a timely } \\
\text { manner in routine } \\
\text { situations }\end{array}$ & $\begin{array}{l}\text { Performs administrative } \\
\text { tasks and patient care } \\
\text { responsibilities in a timely } \\
\text { manner in complex or } \\
\text { stressful situations }\end{array}$ & $\begin{array}{l}\text { Proactively implements } \\
\text { strategies to ensure that } \\
\text { the needs of patients, } \\
\text { teams, and systems are } \\
\text { met }\end{array}$ & $\begin{array}{l}\text { Creates strategies to } \\
\text { enhance other's ability to } \\
\text { efficiently complete } \\
\text { administrative tasks and } \\
\text { patient care } \\
\text { responsibilities }\end{array}$
\end{tabular}

Comments:

Not Yet Completed Level 1 


\section{Professionalism 4: Knowledge of Systemic and Individual Factors of Well-Being*}

\begin{tabular}{|l|l|l|l|l|}
\hline Level 1 & Level 2 & Level 3 & Level 4 & Level 5 \\
\hline $\begin{array}{l}\text { Recognizes the } \\
\text { importance of getting } \\
\text { help when needed to } \\
\text { address personal and } \\
\text { professional well-being }\end{array}$ & $\begin{array}{l}\text { Lists resources to support } \\
\text { personal and professional } \\
\text { well-being }\end{array}$ & $\begin{array}{l}\text { With prompting, reflects } \\
\text { on how personal and } \\
\text { professional well-being } \\
\text { may impact one's clinical } \\
\text { practice }\end{array}$ & $\begin{array}{l}\text { Reflects on actions in real } \\
\text { time to proactively } \\
\text { respond to the inherent } \\
\text { emotional challenges of } \\
\text { physician work }\end{array}$ & $\begin{array}{l}\text { Participates in } \\
\text { institutional changes to } \\
\text { promote personal and } \\
\text { professional well-being }\end{array}$ \\
\hline Comments: & $\begin{array}{l}\text { Recognizes that } \\
\text { institutional factors affect } \\
\text { well-being } \\
\text { factors that affect well- } \\
\text { being }\end{array}$
\end{tabular}

Comments:

Not Yet Completed Level 1

${ }^{\star}$ This subcompetency is not intended to evaluate a resident's well-being. Rather, the intent is to ensure that each resident has the fundamental knowledge of factors that impact well-being, the mechanism by which those factors impact well-being, and available resources and tools to improve well-being.

\section{Professionalism}

The resident is demonstrating satisfactory development of the knowledge, skill, and attitudes/behaviors needed to advance in the training program. The resident is demonstrating a learning trajectory that anticipates the achievement of competency for unsupervised practice that includes the delivery of safe, effective, patient-centered, timely, efficient, and equitable care.

Yes No

Conditional on Improvement 


\section{Interpersonal and Communication Skills 1: Patient- and Family-Centered Communication}

\begin{tabular}{|l|l|l|l|l|}
\hline Level 1 & Level 2 & Level 3 & Level 4 & Level 5 \\
\hline $\begin{array}{l}\text { Uses language and non- } \\
\text { verbal behavior to } \\
\text { demonstrate respect and } \\
\text { establish rapport }\end{array}$ & $\begin{array}{l}\text { Establishes and maintains } \\
\text { a therapeutic relationship } \\
\text { using effective } \\
\text { communication behaviors } \\
\text { in straightforward } \\
\text { encounters }\end{array}$ & $\begin{array}{l}\text { Establishes and maintains } \\
\text { a therapeutic relationship } \\
\text { using effective } \\
\text { communication behaviors } \\
\text { in challenging patient } \\
\text { encounters } \\
\text { Identifies common } \\
\text { barriers to effective } \\
\text { communication }\end{array}$ & $\begin{array}{l}\text { Establishes and } \\
\text { maintains therapeutic } \\
\text { relationships using } \\
\text { shared decision making, } \\
\text { regardless of complexity } \\
\text { barriers to effective } \\
\text { communication, including } \\
\text { personal bias }\end{array}$ & $\begin{array}{l}\text { Coaches others in } \\
\text { developing and } \\
\text { maintaining therapeutic } \\
\text { relationships and } \\
\text { mitigating communication } \\
\text { barriers }\end{array}$ \\
\hline
\end{tabular}

Comments: 


\section{Interpersonal and Communication Skills 2: Interprofessional and Team Communication}

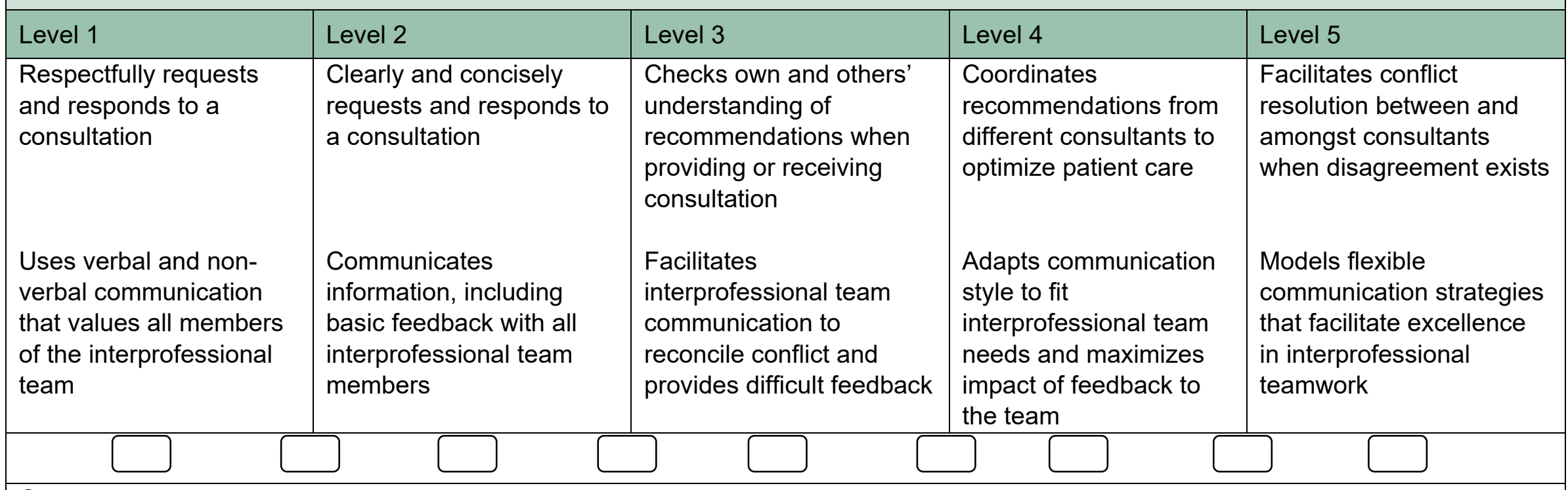

Comments:

Not Yet Completed Level 1 


\section{Interpersonal and Communication Skills 3: Communication within Health Care Systems}

\begin{tabular}{|c|c|c|c|c|}
\hline Level 1 & Level 2 & Level 3 & Level 4 & Level 5 \\
\hline $\begin{array}{l}\text { Accurately documents } \\
\text { comprehensive and } \\
\text { current information }\end{array}$ & $\begin{array}{l}\text { Documents clinical } \\
\text { encounter, including } \\
\text { reasoning, through } \\
\text { organized notes }\end{array}$ & $\begin{array}{l}\text { Documents clinical } \\
\text { encounter through } \\
\text { concise and thorough } \\
\text { notes }\end{array}$ & $\begin{array}{l}\text { Documents clinical } \\
\text { encounter clearly, } \\
\text { concisely, timely, and in } \\
\text { an organized form, } \\
\text { including anticipatory } \\
\text { auidance }\end{array}$ & $\begin{array}{l}\text { Guides departmental or } \\
\text { institutional } \\
\text { communication policies } \\
\text { and procedures }\end{array}$ \\
\hline $\begin{array}{l}\text { Communicates using } \\
\text { formats specified by } \\
\text { institutional policy to } \\
\text { safeguard patient } \\
\text { personal health } \\
\text { information }\end{array}$ & $\begin{array}{l}\text { Selects direct (e.g., } \\
\text { telephone, in-person) and } \\
\text { indirect (e.g., progress } \\
\text { notes, text messages) } \\
\text { forms of communication } \\
\text { based on context, with } \\
\text { assistance }\end{array}$ & $\begin{array}{l}\text { Appropriately selects } \\
\text { direct and indirect forms } \\
\text { of communication based } \\
\text { on context }\end{array}$ & $\begin{array}{l}\text { Models effective written } \\
\text { and verbal } \\
\text { communication }\end{array}$ & \\
\hline
\end{tabular}

Comments:

Not Yet Completed Level 1

\section{Interpersonal and Communication Skills}

The resident is demonstrating satisfactory development of the knowledge, skill, and attitudes/behaviors needed to advance in the training program. The resident is demonstrating a learning trajectory that anticipates the achievement of competency for unsupervised practice that includes the delivery of safe, effective, patient-centered, timely, efficient, and equitable care.

Yes No Conditional on Improvement 


\section{Overall Clinical Competence}

This rating represents the assessment of the resident's development of overall clinical competence during this year of training:

Superior: Far exceeds the expected level of development for this year of training

Satisfactory: Always meets and occasionally exceeds the expected level of development for this year of training

Conditional on Improvement: Meets some developmental milestones but occasionally falls short of the expected level of development for this year of training. An improvement plan is in place to facilitate achievement of competence appropriate to the level of training.

Unsatisfactory: Consistently falls short of the expected level of development for this year of training. 